\title{
EFFECT OF PANTETHINE TREATMENT ON VIBRA- TORY PERCEPTION IN PATIENTS WITH DIABETIC NEUROPATHY
}

\author{
YUKIO SHIGETA, MITSURU HOSHI, MOTOAKI SHICHIRI, \\ KIICHI OJI*, MATAEMON TOMOBUCHI* \\ AND MITSUMI KOSUGI*1
}

The First Department of Medicine, Osaka University Medical School, Osaka and *Sakai City Hospital, Sakai

(Received July 8, 1966)

It is well known that neuropathy is one of the common complications of diabetes mellitus. In such patients an elevated threshold of vibratory perception is frequently observed together with synptoms from the peripheral sensory nerves such as sense of fatigue and paresthesia and pain in extremities, or reduction or disappearance of tendon reflex. We previously reported on disturbance of $\alpha$-keto acid metabolism as a part of disturbance of glucose oxidation in the pathogenesis of diabetic neuropathy and on improved vibratory perception in extremities of ten observed with improvement in subjective symptoms following treatment with thiamine tetrahydrofurfuryl disulfide, a derivative of thiamine that has been considered to be highly histotropic (1). Pantethine, a derivative of pantothenic acid, was used in the present experiment as another vitamin participating in the oxidation of $\alpha$ keto acids to study its effect on the disease.

\section{EXPERIMENTAL}

Vibratory perception test on extremities along with recording of the history and physical findings was performed in 16 cases of diabetes mellitus. Vibratory perception was estimated using biothesiometer at the tip of index finger and great toe, at the frequency of $200 \mathrm{cycle} / \mathrm{sec}$. Minimum perceptible amplitude was regarded as a threshold of vibratory perception and expressed in relative unit of perception, $\mathrm{dB}$.

Pantethine was administered orally in these cases in daily doses of $30-200 \mathrm{mg}$ for 20-70 days and the change in subjective symptoms, patellar reflex, calf tenderness and threshold of vibratory perception was studied. A variation of over $\pm 5 \mathrm{~dB}$ in vibratory perception in either left or right finger or toe was regarded as significant.

In some cases, the increasing ratio of urinary excretion of pyruvate 1 and 2 hours after intravenous injection of $20 \mathrm{ml}$ of $20 \%$ fructose was determined following Sawada's method (2) to evaluate the effect of pantethine on $\alpha$-keto acid metabolism.

\footnotetext{
1 繁田幸男, 星 充, 七里元亮, 王子喜一, 友淵又右衛門, 小杉光美.
} 


\section{RESULTS}

\section{Effect of Pantethine on Vibratory Perception in Extremities}

Pantethine was effective in improving paresthesia or pain of extremities in 4 $(33 \%)$ out of 12 cases and patellar reflex in $6(40 \%)$ of 15 cases among 16 cases of diabetics, causing aggravation of subjective symptoms in only 2 cases $(13 \%)$. However, calf tenderness was not alleviated distinctly (Table 1).

TABLE I

Effect of Pantethine Treatment on Symptoms, Signs and Vibratory Perception in Diabetics

\begin{tabular}{lccccc}
\hline & $\begin{array}{c}\text { Subjective } \\
\text { symptoms }\end{array}$ & $\begin{array}{c}\text { Patellar } \\
\text { reflex }\end{array}$ & $\begin{array}{c}\text { Calf } \\
\text { tenderness }\end{array}$ & \multicolumn{2}{c}{ Vibratory perception } \\
\cline { 5 - 6 } & 4 & 6 & 2 & 5 & 10 \\
Index finger & Great toe \\
Nonprovement & $(33 \%)$ & $(40 \%)$ & $(25 \%)$ & $(45 \%)$ & $(72 \%)$ \\
No change & 7 & 7 & 3 & 6 & 2 \\
Aggravation & $(59 \%)$ & $(47 \%)$ & $(38 \%)$ & $(54 \%)$ & $(14 \%)$ \\
& 1 & 2 & 3 & 0 & 2 \\
$\begin{array}{l}\text { No abnormalities } \\
\text { before the treatment }\end{array}$ & 4 & $(13 \%)$ & $(38 \%)$ & $(0 \%)$ & $(14 \%)$ \\
\end{tabular}

The substance was found highly effective in improving vibratory perception of extremities: effective in $5(45 \%)$ of 11 cases with abnormal threshold for index finger and in $10(72 \%)$ of 14 cases for great toe.

The change in threshold of vibratory perception in extremities resulted from pantethine treatment in each case is shown in Table 2.

TABLE 2

Effect Pantethine Treatment on Vibratory Perception in Diabetics

\begin{tabular}{|c|c|c|c|c|c|c|c|c|c|c|}
\hline \multirow{3}{*}{ Name } & \multirow{3}{*}{$\begin{array}{l}\text { Age } \\
\text { and } \\
\text { sex }\end{array}$} & \multirow{3}{*}{$\begin{array}{l}\text { Duration } \\
\text { of } \\
\text { treatment }\end{array}$} & \multicolumn{8}{|c|}{ Vibratory perception $(d B)$} \\
\hline & & & \multicolumn{4}{|c|}{ Before the treatment } & \multicolumn{4}{|c|}{ After the treatment } \\
\hline & & & rIF & $1 \mathrm{IF}$ & $\mathrm{rGT}$ & $1 \mathrm{GT}$ & rIF & IIF & $\mathrm{rGT}$ & $1 G T$ \\
\hline & & days & & & & & & & & \\
\hline A & $77 \mathrm{~m}$ & 40 & +7 & +1 & +16 & +18 & +7 & +2 & +14 & +12 \\
\hline $\mathrm{N}$ & $65 \mathrm{~m}$ & 60 & -10 & -12 & $\begin{array}{r}10 \\
+\quad 8\end{array}$ & +6 & -10 & $\begin{array}{r}4 \\
-\quad 3\end{array}$ & +11 & +16 \\
\hline $\mathrm{K}$ & $65 \mathrm{~m}$ & 50 & +10 & -10 & +8 & +10 & 0 & -15 & +10 & -9 \\
\hline $\mathrm{T}$ & $64 \mathrm{~m}$ & 60 & -2 & -6 & +15 & +17 & -2 & -2 & +2 & +3 \\
\hline $\mathrm{K}$ & $64 \mathrm{f}$ & 40 & -2 & -4 & +19 & +19 & -2 & -4 & +14 & +14 \\
\hline $\mathrm{H}$ & $61 \mathrm{~m}$ & 40 & -14 & -13 & +20 & +19 & -13 & -20 & +10 & +5 \\
\hline $\mathrm{K}$ & $61 \mathrm{f}$ & 40 & +14 & +1 & +14 & $+\mathrm{I} 6$ & +3 & -9 & -9 & -9 \\
\hline A & $60 \mathrm{f}$ & 30 & +14 & +8 & +20 & +20 & +6 & 0 & +20 & +17 \\
\hline I & $59 \mathrm{f}$ & 20 & -8 & -1 & +15 & +15 & -13 & -13 & +8 & +2 \\
\hline $\mathrm{A}$ & $59 \mathrm{f}$ & 20 & -13 & -13 & $\begin{array}{r}18 \\
+\quad 8\end{array}$ & $\begin{array}{r}10 \\
+\quad 7\end{array}$ & -15 & -15 & +2 & +1 \\
\hline I & $57 \mathrm{f}$ & 60 & -2 & -4 & +6 & +8 & -4 & -2 & +4 & +8 \\
\hline $\mathrm{N}$ & $56 \mathrm{f}$ & 40 & $+1 \overline{1}$ & +14 & +20 & +18 & +1 & -3 & +11 & +17 \\
\hline $\mathrm{T}$ & $46 f$ & 40 & -8 & -8 & +8 & $\begin{array}{r}+7 \\
+\end{array}$ & -9 & -5 & +13 & +12 \\
\hline $\mathrm{T}$ & $46 \mathrm{f}$ & 70 & -8 & -10 & +20 & +20 & -11 & -10 & $\begin{array}{r}15 \\
+15\end{array}$ & +5 \\
\hline $\mathrm{I}$ & $41 \mathrm{f}$ & 40 & -16 & -17 & -1 & -1 & -19 & -19 & -2 & -4 \\
\hline \multirow[t]{2}{*}{$\mathrm{T}$} & $15 \mathrm{f}$ & 40 & -10 & -13 & -7 & -8 & -14 & -18 & -9 & -11 \\
\hline & \multicolumn{2}{|c|}{ Average } & -2.3 & -5.4 & +11.8 & $+\mathbf{1 1 . 9}$ & -5.9 & -5.8 & +7.1 & +4.9 \\
\hline
\end{tabular}

$r$, right; 1, left; IF, index finger; GT, great toe 


\section{Effect of Pantethine on Pyruvate Metabolism}

The increasing ratio of urinary excretion of pyruvate 1 and 2 hours after intravenous injection of $20 \mathrm{ml}$ of $20 \%$ fructose was measured in 10 diabetic patients to evaluate the effect of pantethine on $\alpha$-keto acid metabolism. Distinctly reduced ratio was observed in 7 cases, the average values for the 1 st and 2 nd hour decreased from 3.89 and 2.57 to 2.59 and 1.48 , respectively (Table 3 ).

TABLE 3

Increasing ratio of Urinary Pyruvate Following Fructose Loading Before and After Pantethine Treatment

\begin{tabular}{ccccccc}
\hline \multirow{2}{*}{ Name } & $\begin{array}{c}\text { Age } \\
\text { and sex }\end{array}$ & \multicolumn{2}{c}{ Before treatment } & & \multicolumn{2}{c}{ After treatment } \\
\cline { 3 - 4 } & & lst hr & 2nd hr & & 1st hr & 2nd hr \\
\hline $\mathrm{A}$ & $77 \mathrm{~m}$ & 6.25 & 3.96 & & 1.21 & 1.00 \\
$\mathrm{~N}$ & $65 \mathrm{~m}$ & 2.10 & 1.21 & & 3.73 & 2.87 \\
$\mathrm{~K}$ & $65 \mathrm{~m}$ & 2.46 & 2.46 & & 1.71 & 0.93 \\
$\mathrm{~K}$ & $64 \mathrm{f}$ & 1.97 & 2.78 & & 1.37 & 1.37 \\
$\mathrm{~K}$ & $61 \mathrm{f}$ & 6.43 & 4.74 & & 4.67 & 3.49 \\
$\mathrm{~A}$ & $60 \mathrm{f}$ & 1.74 & 2.26 & & 1.33 & 0.91 \\
$\mathrm{I}$ & $57 \mathrm{f}$ & 1.90 & 1.41 & & 2.38 & 0.85 \\
$\mathrm{~N}$ & $56 \mathrm{f}$ & 9.28 & 3.96 & & 2.99 & 0.95 \\
$\mathrm{~T}$ & $46 \mathrm{f}$ & 3.40 & 1.77 & & 3.94 & 1.65 \\
$\mathrm{I}$ & $41 \mathrm{f}$ & 3.38 & 1.10 & & 2.53 & 1.18 \\
& \multirow{2}{*}{ Average } & $\mathbf{3 . 8 9}$ & $\mathbf{2 . 5 7}$ & & $\mathbf{2 . 5 9}$ & $\mathbf{1 . 4 8}$ \\
& & $\mathbf{0 . 8 1}$ & $\mathbf{0 . 3 7}$ & & $\mathbf{0 . 3 9}$ & $\pm \mathbf{0 . 3 0}$ \\
\hline
\end{tabular}

\section{DISCUSSION}

Pathologically, diabetic neuropathy consists mainly of changes such as extensive fatty degeneration and demyelinization of peripheral nerves. Tasaka (3) reported that disturbance of the peripheral circulation including decreased number of capillaries and severe stenosis of small arteries in the nervous tissues is closely related to the etiology of the disease.

Diabetic neuropathy, however, involves not only disturbance of glucose oxidation due to relative insulin deficiency in the body but that of lipid synthesis, which may contribute considerably to the manifestation of the disease. Shichiri (4) found that similar metabolic abnormalities were present in peripheral nervous tissue in diabetes mellitus, as the reduced production of $\mathrm{C}^{14} \mathrm{O}_{2}$, increased $\mathrm{C}^{14}$ incorporation into lactic acid and decreased $\mathrm{C}^{14}$ incorporation into lipid from glucose-U-C ${ }^{14}$ that were observed in the sciatic nervous tissue of rabbits with alloxan diabetes.

We previously reported on the improvement in vibratory perception in extremities and normalization of $\alpha$-keto acid metabolism brought about by administration of thiamine tetrahydrofurfury disulfide to patients with diabetic neuropathy. Similar effect was observed this time following pantethine treatment. Similar effect was observed this time following pantethine treatment.

Pantethine is a precusor of coenzyme A, one of the coenzymes participating in the oxidation of $\alpha$-keto acids and represents the oxidized form of pantethine, a compound of pantothenic acid with $\beta$-mercaptoethylamine (5). It is more proxymal to coenzyme $\mathrm{A}$ on the route of biosynthesis of the latter than pantothenic acid 
and may be supposed to be more histotropic. On microbiologically estimated urinary excretion of the two substances injected intramuscularly in humans, we found that the sum of the amounts of the two substances in urine following pantethine loading was significantly smaller than the amount of pantothenic acid in urine following its loading (6).

Pantethine treatment proved effective in many of the patients with diabetic neuropathy in improving the patellar reflex or vibratory perception in extremities and especially effective against disturbance of vibratory perception in great toe, but less effective in alleviating subjective symptoms. It is noteworthy in this connection that a correlation was established between normalization of pyruvate metabolism and improvement in vibratory perception in extremities following pantethine therapy.

\section{SUMMARY}

1. Pantethine was administered to patients with diabetic neuropathy in daily doses of $30-200 \mathrm{mg}$ for $20-70$ days to study its clinical effectiveness.

The substance was found effective in improving the patellar reflex or vibratory perception in extremities in some cases and especially effective against disturbance of vibratory perception in toe.

2. The increasing ratio of urinary excretion of pyruvate following intravenous injection of fructose was reduced in many cases by pantethine treatment. A correlation was noted between normalization of pyruvate metabolism and improvement in vibratory perception in extremities.

\section{ACKNOWLEDGEMENT}

The authors wish to express their thanks to Prof. Hiroshi Abe, Chairman of the First Department of Medicine, Osaka University Medical School, and to Prof. Masahisa Wada, Osaka City University Medical School, for their kind advice and encouragement. The excellent technical assistance of Miss Chizuko Matsushita is gratefully acknowledged.

\section{REFERENCES}

1. Wada, M., Shigeta, Y., Nakamura, K., and Shichiri, M., Vitamins 29, 249 (1964).

2. Sawada, T., and Miyaji, K., Fukuoka Med.J. (Japanese) 42, 369 (1951).

3. Tasaka, H., Diabetes (Japanese) 7, 26 (1964).

4. Shichiri, M., Med. J. Osaka Uuiv. 14, 159 (1963).

5. Hoagland, M. B. and Novelli, G. D., J. Biol. Chem. 207, 767 (1954).

6. Shigeta, Y. and Shichiri, M., in press. 